\title{
SUMÁRIO
}

\author{
Editorial
}

5

As tendências pós-modernas em busca de compensações o contra-peso do multiculturalismo crítico

Marcos Antonio C. Silva

7

Modernidade e educação: as relações e os desafios do homem diante das antigas e novas formas de conhecimento

\section{Ezir George Silva}

15

A leitura e a textualização do lúdico na diversidade cultural

Helena Confortin

Paulo M. Mescka

Ana M. Dal Zott Mokva

45

O gênero notícia: diagnóstico e intervenção

Silvia Regina Emiliano

73

O gênero diário na formação inicial do professor

Cláudia Valéria Doná Hila

99

O desenho: um processo de ensino, aprendizagem e desenvolvimento do processo criativo

Marcia Moreno

121 
Trabalho, educação e deficiência mental: a inclusão laboral como fator de desenvolvimento humano

Solange Maria Alves

Susane Cristina Thebaldi Veber

Rosely Catarina Fritzen Scheid

143

Hitler-Jugend: "verdadeiras escolas" do Terceiro Reich

Célia Toledo Lucena

163

Entrevista

Avaliação na universidade: alguns desafios

Mara De Sordi

185 


\section{EDITORIAL}

Dando continuidade às discussões sobre a questão da modernidade e pós-modernidade já colocadas no número anterior da revista, este número apresenta duas contribuições na direção de uma leitura crítica das tendências pedagógicas pós-modernas, que permeiam as políticas públicas e os impactos da modernidade sobre a educação: a primeira delas é sobre o discurso pós-moderno e suas inflexões na educação, de Marcos Antonio Silva, principalmente a forma como essas tendências têm permeado as políticas públicas. No percurso feito, o autor realça as contribuições de Peter Mclaren como possível referência na construção de políticas educacionais críticas e de resistência. A outra contribuição é de Ezir Silva, apresentando o resultado de pesquisa com professores da Faculdade de Filosofia, Ciências e Letras de Caruaru (FAFICA). O estudo teve como objetivo analisar e interpretar as falas dos sujeitos para ampliar a compreensão dos discursos e debates sobre o racionalismo, relativismo, pluralidade, modernidade e pós-modernidade no contex to educacional.

Os artigos seguintes estão voltados para a reflexão sobre leitura e escrita, estejam elas relacionadas à ludicidade, à preocupação do resgate de valores e vivências da diversidade cultural, ou ao prazer de vivenciar a prática de ler e de escrever como uma verdadeira experiência sóciohistórico-cultural. Embora muitas pesquisas já tenham sido feitas sobre a prática de leitura e escrita em nossas escolas, o desafio de fornecer subsídios teóricos e metodológicos para auxiliar a prática pedagógica dos professores continua. Algumas possibilidades de ampliar, em sala de aula, espaço para o exercício da leitura e da escrita são apresentadas nos textos desse bloco.

O artigo seguinte, de Márcia Moreno, trata do desenho como linguagem e de sua importância no desenvolvimento do sujeito. A autora desmistifica a idéia de que a criação apenas resulta de um momento de iluminação, mas é fruto da significação dada ao mundo pelo sujeito, da sua imaginação produtiva ou criadora e, nessa direção, a relevância do papel de outros sujeitos nesse processo, principalmente do professor, é muito significativa.

Solange Alves, Susane Veber e Rosely Scheid mostram, a partir do enfoque histórico-cultural, as mudanças ocorridas no processo de desenvolvimento psicológico de pessoas com deficiência mental em processo de inclusão no mercado de trabalho. 
Para explicitar o quanto a política nazista fascinou os jovens, Célia Lucena apresenta resultados de pesquisa cujos dados foram colhidos através dos depoimentos de grupos diferenciados de alemães que durante a juventude participaram na Alemanha do Terceiro Reich. Além de ouvir as vozes vindas das entrevistas, leitura de documentos transcritos nos diferentes arquivos da cidade de São Paulo, a autora vai mostrando como esse discurso educacional vai tomando conta do imaginário da Hitler-Jugend. E, ainda, como essas "novas idéias" foram construídas no imaginário dos investigados, mostrando como as estratégias de divulgação dos valores nazistas elaborado pela Alemanha, estavam impregnadas no discurso educacional.

Por último, colocamos em foco entrevista feita à professora Mara Regina Lemes De Sordi, da Universidade Estadual de Campinas (Unicamp), com foco no tema da Avaliação da aprendizagem, num espaço do momento de trabalho que realizou junto aos professores da Unochapecó. 